negative order doctrine operates only to preclude attacks by statutory injunction. ${ }^{148}$

Conclusion. While control of appealability rests largely in the hands of the courts, the influence which can be exercised by the legislative draftsman is not inconsiderable. Statutes clearly can determine the stage at which orders may be attacked. And since indiscriminate appeals are incompatible with administrative efficiency, final orders from which appeals may be taken should be specified in newly-enacted statutes. Legislative draftsmen who wish to prevent appeals entirely may have a more difficult task. If the statute is framed in terms of pure discretion, and if no provision is made for a hearing, the chances of precluding appeals may be somewhat enhanced. Perhaps a more sucessful method of limiting appeals would be to provide for review under the terms of the Urgent Deficiencies Act; the negative order doctrine might then be applied. And finally, appeals by parties other than those on whom an order directly operates can probably be warded off by specific provision denying private parties the right of appeal.

\title{
CONFIDENTIAL TREATMENT OF INFORMATION REQUIRED BY THE SECURITIES EXCHANGE ACT
}

The discLosure provisions of the Securities Exchange Act ${ }^{1}$ are an integral portion of a statute which aims to provide investors with the data necessary to formulate intelligent judgments as to the value of corporate securities. In a simpler day, corporate capital was ordinarily derived from the sale of stock to the entrepreneurs who managed the companies or to local investors who could inform themselves directly about the companies' affairs. ${ }^{2}$ If those persons were barred from information and had reasonable grounds for seeking it, equity would give them access to books and papers. ${ }^{3}$ But this privilege was not granted to bondholders or prospective investors, ${ }^{4}$ and, though some-

148. In its most recent decision in the field, the Supreme Court has indicated by way of dictum that the negative order doctrine operates only to preclude the special type of review procedure of the Urgent Deficiencies Act. See United States v. Griffin, 58 Sup. Ct. 601, 607 (1938); Watkins, Has a Shipper Who Has Been Denied Ralicf by the Interstate Commerce Commission Any Remedy? (1917) 17 CoL. L. REv. 34, 42. Cf. Louisville \& N. R.R. v. Garrett, 231 U. S. 298, 311 (1913). (1934).

1. Securities Exchange Act $\S \S 12,13,48$ STat. 892, 894, 15 U. S. C. $\S \S 78(1)$, (m),

2. 2 Davis, Essays in the Earlier History of American Corporations (1917) 298-303.

3. Guthrie v. Harkness, 199 U.S. 148 (1905); Varney v. Baker, 194 Mass. 239, 80 N. E. 524 (1907); In re Steinway, 159 N. Y. 250, 53 N. E. 1103 (1889).

4. The privilege was limited strictly to actual stockholders. 5 FleTCuER, Conporations, $\$ \S 2213,2230$. But several statutes have extended it to creditors. Id., at $\S 2236$. 
what extended by statutes, 5 is of negligible value to the ten million-odd "owners" of the modern corporation. 6 Consequently, prior to the passage of the Exchange Act and its counterpart, the Securities Act, ${ }^{7}$ investors were forced to appraise security values on the basis of voluntarily published corporate reports, ${ }^{8}$ most of which were fragmentary even when regulated by the various stock exchanges, ${ }^{9}$ and some of which served as a cloak for incompetence and dishonesty. ${ }^{10}$

To remedy these evils the Exchange Act imposes upon all corporations whose securities are listed on exchanges the standard of full disclosure which the Securities Act requires of corporations floating new issues. ${ }^{11}$ As a prerequisite to listing its securities, a corporation must file with the Securities and Exchange Commission and with the exchange an application including its history, structure, officers and directors and their remuneration, balance sheets, and profit and loss statements, ${ }^{12}$ all of which must be kept up to date by periodical supplemental reports. ${ }^{13}$ The Act lists only the subjects and persons about whom information must be given. The extent of disclosure is left to the Commission, which is authorized to prescribe by rules and regulations the detail "necessary or appropriate in the public interest or for the

5. E.g., Shea v. Parker, 234 Miass. 592, 126 N. E. 47 (1920) (statute held to grant absolute right of inspection of stock book); N. Y. STock Conp. LAw $\$ 77$ (holder of $3 \%$ of shares can require treasurer to furnish a sworn balance sheet irrespective of reason).

6. In many large corporations, it is probable that no one person, outside of management groups, owns enough stock to exercise the power granted in N. Y. Srocts Corp. LaW \$77, stpra note 5. See Berle aNd afenNs, afodern Corponation aud Private Property (1932) 47, 97-110.

7. 48 Stat. 74 (1933), as amended 48 Stat. 905 (1934), 15 U.S.C. $\$ 77$ (a) (1934).

8. Publication has not been voluntary in every instance. A Massachusetts statute requires an annual report including a balance sheet independently audited. Mass. Ger. LAws (1932) c. 156, $\$ \$ 47,49$. Carriers and utilities must report to various regulatory bodies. See Comment (1935) 44 Yare L. J. 819, 833-4.

9. See Ripley, Main Street and Wall Street (1927), c. 6, 7; Farr, The Annual Corporate Report: A Study in Evasion (1934) 168 HAnper's RLAGazne 421. The New York Stock Exchange made efforts to raise the level of reporting by its listing requirements. Twentieth Century Fund, The Securrty Mlarkets (1935) 576, 592, 602. But enforcement often was lax. See id., at 584, n. 1; SEsr. REP. No. 1455, 73d Cong. 2d. Sess. (1934) 70.

10. See Reis, False Securtty (1937); Sen. Rep. No. 1455, 73d Cong., 2d Sess. (1934) 55-73, 205-20.

11. Compare $\$ 12(b)$ of the Securities Exchange Act with Schedule $A$ of the Securities Act. Comparable forms are Form 10 under the Securities Exchange Act [C. C. H. St. Exch. Reg. Serv. I6511], and Form A-2 under the Securities Act [C. C. H. Securities Act Serv. \6651]. The issue of new securities of course requires extensive disclosures unnecessary in Form 10. See AfacChesney and O'Brien, Full Disclosure Under the Securities Act, (1937) 4 Law \& Contearp. Prob. 133.

12. $\$ 12(\mathrm{~b})$.

13. $\$ 13(\mathrm{a})$. 
protection of investors."14 Presumably, the precedent of the Securities Act could have been followed, and these rules and regulations could be applied without exception to all corporations seeking the privilege of listing..$^{16}$ But the Act provides two safeguards to avoid undue hardship in individual cases. Section 24(a) permits a registrant to withhold entirely from the Commission trade secrets and processes, and Section 24(b) provides that upon written objection to the disclosure of any information, the Commission may hold a hearing "where it deems it advisable" and may "make available to the public the information ... only when in its judgment a disclosure . . is in the public interest." 16

Numerous objections to publication have been filed under Section $24(\mathrm{~b}),{ }^{17}$ and fifteen suits are pending in the Circuit Courts of Appeals contesting denials of confidential treatment. ${ }^{18}$ Their disposition depends, first, upon an interpretation of the statutory provisions and, second, upon a decision as to the proper scope of judicial review of administrative action.

The statutory standards which guide the Commission in laying down rules and in granting exemptions from the rules are not identical. For the former the standard is "the public interest or the protection of investors;" for the latter, it is "the public interest" alone. This verbal difference, however, seems immaterial, for the public interest involved in these provisions is the protection of investors. ${ }^{19}$ But the considerations which lead to the

14. Section 12(b)(1); cf. $\$ 13(\mathrm{~b})$. Rules and regulations are not appealable but may be enjoined if arbitrary or an unreasonable interpretation of the statute. Third Ave. Ry. v. Securities Exchange Commission, 85 F. (2d) 914 (C. C. A. 2d, 1936); see Blachly and Oataran, Administrative Legislation and Adjudication (1934) c. 4.

15. The Securities Act provides for exemption from its disclosure requirements in only one respect. Portions of material contracts may be withheld if the Commission determines that disclosure would impair the value of the contract and is not necessary for the protection of investors. Schedule A, $\llbracket 30,48$ STAT. 91 (1933), 15 U. S. C. $\$ 77$ (aa) (1934). In the year ending June 30,1937, 68 requests were made for confidential treatment under Rule No. 580 [C. C. H. Securities Act Serv. 15580 ] which embodies this exemption. Sixty-six were granted. S.E.C. ThIRd ANNuAt Report (1937) 63. Cf. Rule No. 581 [C. C. H. Securities Act Serv. If 5581]. The Securities Exchange Act does not require disclosure of material contracts, as described in Schedule $A, \Uparrow 24$, of the Securities Act, except management and service contracts. $\$ 12(b)(1)(G)$.

16. 48 STAT. 901,15 U. S. C. $\$ 78(\mathrm{x})$ (1934).

17. In the year ending June $30,1936,631$ registrants objected to publication of 966 items of information, and 218 companies objected to disclosure of material in annual reports. See S. E. C. SECond Annual Report (1936) 25.

18. Thirty-one petitions for review have been filed, but sixteen have been voluntarily dismissed. See S. E. C. ThIRD Annual Report (1937) 179, giving circuit, date of filing, and status of each.

19. Sen. Rep. No. 792, 73d Cong. 2d Sess. (1934) 10-11; H. R. Rep. No. 1383, 73d Cong. 2d Sess. (1934) 11-13. "The public interest," a valid guide for administrative action, refers not to the public welfare generally but to the context and purpose of the Act. New York Central Sec. Corp. v. United States, 287 U. S. 12 (1932); Federal Radio Commission v. Nelson Bros. Bond \& Mtge. Co., 289 U. S. 266, 285 (1933). 
promulgation of general rules of disclosure are, of course, not always the same as those involved in adjudicating a petition for exemption from a rule. Although disclosure of a particular item may be in the interest of the investing public and may work no hardship on corporations generally, it may cause injury to an individual corporation far outweighing the benefit conferred on security holders by publicity. The treatment accorded salaries and profit and loss statements illustrates the Commission's recognition of this distinction.

The statute demands "such information as the Commission may require" concerning the remuneration of officers and directors, and of others earning more than $\$ 20,000$ a year, together with "bonus and profit-sharing arrangements." 20 The share of corporate income which management takes for itself would seem to be a legitimate concern of the investing public, especially in view of the general suspicion in recent years that the proportion is often exorbitant. ${ }^{21}$ On the other hand, there is wide-spread opposition to indiscriminate publication of individual salaries, such as the Revenue Act allows.? It is argued that disclosure arouses intra-company jealousies among minor executives. ${ }^{23}$ The S.E.C., free to determine what serves the interest of investors, has apparently accorded some weight to these claims since it requires the individual salaries only of the directors and the three highest paid officers of a company. For the other officers and employees carning more than $\$ 20,000$, an aggregate amount with the number to whom it is paid suffices. 28 This interpretation of the general public interest seems reasonable. Applicants for confidential treatment have, however, been dissatisfied even with this compromise and have claimed that any interest in salaries is "criminal curiosity" 25 and that publicity will make the rank and file seeth with discontent. $^{26}$ But these arguments are not very compelling, since they overlook the fact that under the Revenue Act corporate salaries over $\$ 15,000$ are already widely publicized, ${ }^{27}$ and since they tend chiefly to deprecate the utility of the information to the public at large- a factor presumably considered by the Commission in promulgating its rules-rather than the requisite injury

20. $\S \S 12(b)(1)(D, E, F)$.

21. See Flynn, What Should a Man Earn? (1933) 90 Forous 3; Balier, Excculite Compensation Compared with Earnings (1936) 14 HARv. Bus. Rev. 213.

22. See N. Y. Times, April 29, 1937, p. 20, col. 2; id., Jan. 11, 1938, p. 22, col. 2.

23. Hearings Before the Commitice on Banking and Currency on $S$. Res. \&4, 72d Cong., and S. Res. 56 and S. Res. 97, 73d Cong. (1934) p. 6686 (Pecora Investigation).

24. Form 10, items 26 and 27. See [C. C. H. St. Exch. Reg. Serv. $\$ \$ 6539,6540$ ].

25. Congoleum-Nairn Petition for Review of denial of confidential treatment, as quoted in N. Y. Times, March 27, 1936, p. 33, col. 8 .

26. See Diajiond Match Coamany, Repoet to Stockgologrs ror 1935 (1936) 172-4; National Biscuit Co. Petition for Review of denial of confidential trentment, as quoted in N. Y. Times, March 27, 1936, p. 33, col. 8.

27. 48 STAT. 727,26 U. S.C. \$148(d) (1934). 
to a particular applicant. The Commission has consequently had little occasion to grant confidential treatment to salary information..$^{28}$

A more stormy history has followed the Act's requirement of "profit and loss statements." 29 The Commission's rules require, among others, four highly important figures: (1) gross sales, (2) cost of goods sold, (3) depreciation and depletion, and (4) selling, general, and administrative expenses..30 These items seem essential, purely as a matter of definition, to a complete profit and loss statement. 31 Though many so-called "income statements" reveal only net earnings or gross profits, ${ }^{32}$ most accountants and expert analysts agree that a complete statement is invaluable in appraising a company's condition and prospects, especially the sales and cost of sales figures. ${ }^{33}$ While skepticism as to the individual investor's ability to analyze them is not unwarranted, the inability arises partly from unfamiliarity, and in any event these figures can be effectively utilized by competent investment counsel, financial manuals, and the financial press. ${ }^{34}$ The most determined opposition arises from business men who traditionally feel that their volume and costs cannot be revealed even in the unanalyzed form required by the Commission without inviting disaster. But' many large corporations have long published them as a matter of course, ${ }^{35}$ and no cases have been found of untoward results directly attributable to compliance with the Act. ${ }^{38}$

While the rules requiring these four figures also seem reasonable, the problem of exemption is more difficult. All fifteen of the pending suits are

28. See statement by then Chairman Landis, N. Y. Times, April 14, 1937, p. 46, col. 1.

29. $\S 12(\mathrm{~b})(1)(\mathrm{J})$.

30. Instruction Book for Form 10. [C. C. H. St. Exch. Reg. Serv. đ6567].

31. See Federal Reserve Board, Verification of Financtal Statements (Rev. ed. 1929) 21, 26; Kester, Advanced Accounting (1933) c. 3; MacFarland and Ayars, Accounting Fundanentals (1936) c. 4; Paton, Accountants' Handdook (1934) 22-64.

32. For a survey of the wide variations in published profit and loss statements, see Sunley, Seen in Published Financial Statements (1935) 15 Certified Pubitc ACCOUNTANT 682.

33. Then Chairman Landis characterized sales and cost of sales as the "most im-' portant" figures in the applications. N. Y. Times, April 14, 1937, p. 46, col. 1. See Robinson, Are Present Forms of Financial Statements Satisfactory? 62 Journal of Accountancy (Dec. 1936) 3, 11, 22; Examination of Financial Siatements, Bulcerin of the American Institute of Accountants (Jan. 1936) 3-4. But cf. Sanders, Accounting Aspects of the Secturities Act (1937) 4 LaW and Cont. Prob. 191, 212.

34. Twentieth Century Fund, The Security Markets (1935) c. 16.

35. In 1927, 235 out of 545 leading industrial corporations published gross income. Sloan, Corporation Profits (1929) 62. For examples of apparently irrational divergences within industries, see Twentietr Century Fund, The Security Markets (1935) 581.

36. See Sanders. Corporate Information Required by Federal Security Legislation 5 N. Y. Certified Public Accountant (April, 1935) 20. 
fighting disclosure of sales and cost of sales figures. ${ }^{37}$ And although the petitioners have advanced varied arguments, two type situations indicate circumstances in which confidential treatment may well be in the public interest. $^{38}$ In the first, a relatively small company, most of whose output is sold to one large buyer, will attempt to show that publication of its margin of profit will give that buyer an additional lever with which to demand lower prices. Second, companies whose competitors need not disclose their margins of profit because they are not listed on any exchange may contend that the latter will acquire various competitive advantages, such as an opportunity to persuade buyers that the registrant's margin of profit, which has become a matter of public record, is excessive. To these arguments economists may reply that buyers are swayed by the prices that sellers offer, not by their margins of profit, while proponents of publicity may add that if a company is in a vulnerable position, investors should know about it.33 For some time, however, the Commission granted confidential treatment rather freely in these type situations. But when investigations revealed that in many cases competitors or customers already had obtained the disputed information either through underhand activities ${ }^{40}$ or from other public records, ${ }^{42}$ and that the figures had little effect upon buying policies, 12 the number of exemptions decreased. 43

These instances show the conflicting interests involved in deciding whether a particular disclosure is in the public interest. In each case the Commission

37. Communication to Yale Law Journal from Securities and Exchange Commission, Oct. 28, 1937.

38. See Morrison, Reports to Stockholders (1935) 10 Accounitizo Review 77, 81-3.

39. See ibid.; Pecora Investigation, supra note 23, at 6533.

40. On the prevalence of industrial espionage, see Pecora Investigation, supro note 23, at 6533; 78 CoNG. REc. 8184 (1934). Legitimate exchange of information through trade associations, and illegitimate monopolistic activities, probably provide far more competitive enlightenment than the figures whose public distribution is protested. $C f$. Burns, The Decitne of Cosipetition (1936) cc. 2, 10.

41. E.g., from franchise tax reports in Georgia, income tax returns in Wisconsin, and reports under blue-sky laws in Michigan. Communication to the YALE LAw Journal from Securities and Exchange Commission, Feb. 1, 1938.

42. See N. Y. World-Telegram, Jan. 11, 1938, p. 24, col. 2, summarizing the findings of a special investigation conducted by the Securities and Exchange Commission.

43. Compare the figures in S. E. C. Second Anwuar. Refort (1936) 25, with those in S.E.C. ThIRd Annual Report (1937) 62. Statistical tabulation is impractical because of the number of applications carried over from one year to the next. It is clear, however, that both applications for, and grants of, confidential treatment have sharply declined. Examination of S.E.C. releases on this subject for the past year indicates that denials of confidential treatment are practically a matter of course. A shift of policy is also suggested by the repeal, in Feb. 1937, of a rule by which grants of confidential treatment under $\$ 24(b)$ could be extended to Securities Act filings by the same company. Securities Act Release No. 1292 [C. C. H. Securities Act Ser: p. $1492(n)]$. 
must balance extravagant forebodings of disaster against the vague yet forceful mandate of the Act. The weight to be ascribed to either is scarcely measurable. Consequently a solution of the question of whether harm is threatened and, if so, whether it outweighs the interest of the investing public, depends more upon an exercise of business judgment than upon an analysis of evidence. For this reason it would seem advisable to leave this question to the Commission's discretion and to permit no appeals.44 This seems to have been Congress' intent, for it rejected an amendment granting a right to a hearing, which is ordinarily a prerequisite to an appeal, 46 and provided that a hearing was to be discretionary. ${ }^{46}$ But the District of Columbia Court of Appeals recently refused to accept this interpretation of the Act.47 Instead, it held that all denials of confidential treatment are appealable and that the language granting hearings in the Commission's discretion meant only that a hearing might be eliminated when confidential treatment was granted, in which case the improbability of an appeal would render a hearing unnecessary. ${ }^{48}$

To justify its conclusion the court accepted allegations that the sales figures were trade secrets and therefore "property" as true, and to avoid constitutional doubts felt constrained to declare that the Commission's decision was "judicial" and consequently subject to review. But there are several objections to this line of reasoning which the court did not consider. In the first place, there is little reason to classify sales figures as trade secrets, for trade secrets are generally said to be processes and formulae rather than the mere privacy with which an ordinary business is conducted. ${ }^{49}$ Secondly, if

44. In analogous situations, an exercise of discretionary power has been held not subject to appeal, and no constitutional objections have been found. Cf. Williamsport Wire Rope Co. v. United States, 277 U. S. 551 (1928) (refusal to grant special tax exemption) ; Louisville \& N. R. R. v. Kentucky, 183 U. S. 503 (1902) ; Baltimore \& Ohio R.R. v. Lambert Run Coal Co., 267 Fed. 776 (C. C. A. 4th, 1920) (exemption from general rule); Procter \& Gamble Co. v. United States, 225 U. S. 282 (1912); 2 Sharfatan, The Interstate Comarerce Commission (1931) 406-17 (riegative orders).

45. Comment (1938) 47 Y AlE L. J. 766, at 778 et seq.

46. Section 24 first appears in its present form in H. R. 9323, $\$ 23$. In conference the Senate attempted to substitute S. $3420, \S 23$ of which gave every objector a right to a hearing. The Committee report on S. 3420 said the determination would be subject to review. Sen. Rep. No. 792, 73d Cong. 2d Sess. (1934) 10. But the House provision was adopted, the Conference report explaining, "that any person . . . might make written objection to disclosure . . . , and the Commission was authorized to hear objections if it deemed it advisable, but in any case the Commission might make the information public despite objection if in its judgment the disclosure was in the public interest." (Italics supplied) H. R. Rep. No. 1838, 73d Cong., 2d Sess. (1934) 37.

47. American Sumatra Tobacco Corp. v. Securities and Exchange Commission, 93 F. (2d) 236 (App. D. C. 1937).

48. A stockholder desiring to intervene and oppose a grant of confidential treatment might possibly be able to appeal. See Comment (1938) 47 YalE L. J. 766, 781.

49. In re Bolster, 59 Wash. 655, 110 Pac. 547 (1910); United States ex rel. Norwegian Nitrogen Products Co., Inc. v. Tariff Commission, 6 F. (2d) 491 (App. D. C. 
sales figures are actually to be considered trade secrets for the purposes of this Act, the petitioners' right to appeal appears dubious at best. Since they could withhold trade secrets from the Commission under Section 24(a), it would seem that their proper administrative remedy was to do so, thus requiring the Commission to take action, ${ }^{50}$ rather than to submit the information and then demand confidential treatment under Section 24(b).

Not only does the court's decision fail to answer these arguments, ${ }^{, 1}$ but its implications in terms of administrative efficiency seem unfortunate. Recalcitrant registrants may easily employ the machinery of appeal to delay publication of reports until they possess only an historical interest. ${ }^{\text {t2 }}$ Although the reviewing court has the power to refuse a stay of disclosure, ${ }^{53}$ most courts will probably hesitate to exercise it, for publication would render the question of confidential treatment moot. Another source of delay resulting from the creation of the privilege to appeal denials of confidential treatment is that the Commission, on request, will now have to preede such orders by a hearing. Furthermore, this necessity of a hearing will impose a considerable burden on the Commission not only by increasing the number of hearings, but also by forcing the Commission itself, since no adversary interests are involved, to produce evidence with which to make a record and sustain its findings. ${ }^{54}$ The difficulties involved in producing evidence which will sustain a finding that disclosure is in the public interest are not to be

1925) ; see Norwegian Nitrogen Products Co. v. United States, 235 U. S. 294, 325 (1933). Cf. Comment (1919) 19 CoL. L. Rev. 233; (1928) 42 Hanv. L. Rev. 254,

50. The Commission would then apply to a district court for a writ of mandamus, under $\$ 21$ (f), or proceed by hearing to suspend the registration, under $\$ 19$ (a) (2).

51. The decision was perhaps influenced by the fact that the Commission's Rule UB2, [C. C. H. St. Exch. Reg. Serv. [ 5402], provided in detail for appeals. The Commission insisted, however, that the procedure was established merely to facilitate a court test of the question of appealability. Reply Brief for Respondent, p. 20, Amerian Sumatra Tobacco Corp. v. Securities and Exchange Commission, 93 F. (2d) 236 (App. D. C. 1937).

52. Annual reports are ordinarily published two or three months after the close of the business year. Twentieta Century Fuxd, The Secunity Minnfers (1935) 591. On the average, the pending appeals were filed almost two years ago. See list in S. E. C. Third Annual Report (1937) 179.

53. $\$ 25(\mathrm{~b})$.

54. See Feller, Prospecius for the Further Study of Administrotize Low (1938) 47 YALE L. J. 647, 665, for a survey of the confused state of the law on findings. The Commission must assuredly make a "basic" finding that the disclosure is in the public interest. United States v. Baltimore \& Ohio R.R., 293 U. S. 454 (1935). But whether subsidiary findings would be required is doubtful. Compare Louisiana v. United States, 290 U. S. 70 (1933), with Atchison, T. \& S. F. Ry. v. United States, 295 U. S. 193 (1935). If they were, the Commission might be somewhat embarrassed in the pending appeals, for its orders denying confidential treatment merely recited that the information was found to be in the public interest. See Petition for Reviev, p. 12, American Sumatra Tobacco Corp. v. Securities and Exchange Commission, 93 F. (2d) 236 (App. D. C. 1937). 
minimized, ${ }^{55}$ especially in view of the highly dramatic form in which objections may be presented. ${ }^{56}$ Some considerations may be difficult of proof, as, for example, a belief of the Commission that the disputed figures are already current among the objector's competitors as a result of underhand activities within the industry. Others are scarcely matters of fact at all. Thus the existence of public interest in full disclosure, which is largely a question of policy, can be translated into evidence only by such colorless devices as quotations from congressional reports and learned authors, methods which would grow less colorful as they were perforce repeated in every record. ${ }^{\text {tr }}$

In these circumstances, it might be well to create a presumption of public interest in any item required by the Commission's rules and to place something akin to the burden of proof upon anyone demanding confidential treatment. The language of the Act may seem to stand in the way, for Section 24(b) permits disclosure, once objections have been raised, only when in the Commission's judgment it is in the public interest. But the position of the word only does not place any burden of proof on the Commission, for its findings are conclusive if supported by substantial evidence. ${ }^{58}$ It may possibly make the Commission less hesitant to grant confidential treatment. Nevertheless, it seems clear that the purpose of the Act is to make publicity the norm and confidential treatment the exception.

55. See Landis, Business Policy and the Courts (1938) 27 YALE Review 235, 247-8, summarizing the factors to be considered and the sources of information to be utilized in these cases: But see Freund, Administrative Powers over Persons and Property (1928) 108.

56. One objector declared that its "very existence would be jeopardized" by disclosure. It has since dismissed its appeal. P. Lorillard Co. Petition for Review of denial of confidential treatment, as quoted in N. Y. Times, March 27, 1936, p. 33, col. 8; see N. Y. Times, April 14, 1937, p. 46, col. 1.

57. It would presumably be necessary to introduce this material at cvery hearing. Cf. United States v. Abilene \& Southern Ry., 265 U. S. 274 (1924).

58. $\S 25(\mathrm{a})$. 